DOI: https://doi.org/10.24127/ajpm.v9i3.2804

\title{
EKSPERIMENTASI MODEL DISCOVERY LEARNING TERHADAP PRESTASI DAN MINAT BELAJAR MATEMATIKA SISWA
}

\author{
Sutrisno $^{1^{*}}$, Nurina Happy ${ }^{2}$, Wiwik Susanti ${ }^{3}$ \\ 1,2,3 Universitas PGRI Semarang, Semarang, Indonesia \\ *Corresponding author. Jl. Sidodadi Timur No. 24, 50232, Semarang, Indonesia. \\ E-mail: $\quad$ sutrisnojr@upgris.ac.id $^{1 *}$ \\ nurinahappy@upgris.ac.id ${ }^{2)}$ \\ wiwiksusanti222@gmail.com $^{3)}$
}

Received 09 May 2020; Received in revised form 11 September 2020; Accepted 17 September 2020

\begin{abstract}
Abstrak
Penelitian ini dilatarbelakangi hasil Ujian Nasional pada mata pelajaran matematika paling rendah dibandingkan dengan mata pelajaran lainnya dan kurangnya minat belajar siswa pada mata pelajaran tersebut. Tujuan penelitian ini adalah untuk mengetahui apakah prestasi dan minat belajar siswa menggunakan model discovery learning lebih baik dari model pembelajaran konvensional. Populasi dalam penelitian ini adalah seluruh siswa kelas VII SMP Negeri 4 Taman Kabupaten Pemalang. Jenis penelitian ini adalah quasi experimental design. Teknik pengambilan sampel dalam penelitian digunakancluster random sampling sehingga terpilih kelas VII D yang diberikan model pembelajaran konvensional, kelas VII H yang diberikan model discovery learning, dan kelas VII A yang digunakan sebagai kelas ujicoba instrumen. Instrumen penelitian meliputites prestasi belajar dan angket minat belajar. Teknik analisis data dalam penelitian ini adalah uji normalitas multivariat, uji homogenitas matriks kovariansi, uji Hotelling Trace $\mathrm{T}^{2}$, dan uji t. Hasil penelitian meunjukkan bahwa prestasi dan minat belajar matematika siswa yang menggunakan model discovery learning lebih baik daripada model pembelajaran konvensional.
\end{abstract}

Kata kunci: Discovery learning; minat belajar; prestasi belajar.

\begin{abstract}
This research is motivated by the National Examination results in the lowest mathematics subjects compared to other subjects and the lack of student interest in learning those subjects. The purpose of this study was to determine whether student achievement and interest in using discovery learning models are better than conventional learning models. The population in this study were all grade VII students of SMP Negeri 4 Taman Kabupaten Pemalang. This type of research is a quasi-experimental design. The sampling technique used in the study is cluster random sampling so that selected class VII D is given a conventional learning model, class VII H is given a discovery learning model, and class VII A is used as a test instrument class. Research instruments include achievement tests and interest in learning questionnaires. Data analysis techniques in this study were multivariate normality test, covariance matrix homogeneity test, Hotelling Trace $T^{2}$ test, and t-test. The results showed that students' mathematics learning achievement and interest in using discovery learning models were better than conventional learning models.
\end{abstract}

Keywords: Discovery learning; interest in learning; learning achievement.

This is an open access article under the Creative Commons Attribution 4.0 International License

\section{PENDAHULUAN}

Matematika merupakan ilmu

yang mempunyai penerapan penting

dalam kehidupan, sehingga sangat penting diberikan di setiap jenjang pendidikan. Untuk mengetahui keberhasilan proses belajar mengajar di setiap jenjang pendidikan dapat dilihat 
dari prestasi belajar yang dicapai oleh peserta didik (Siagian, 2015). Prestasi belajar siswa memperlihatkan bahwa dirinya telah mengalami proses belajar dan telah mengalami perubahanperubahan baik perubahan dalam memiliki pengetahuan, keterampilan, ataupun sikap (Syarif, 2012). Dalam proses belajar matematika sangat diperlukan kesiapan siswa baik dari lingkungan maupun dalam dirinya sendiri (Lestari, 2015).

Prestasi belajar matematika yang masih rendah terjadi pada SMP N 4 Taman Kabupaten Pemalang. Hal itu terlihat dari data Pusat Penilaian Pendidikan, Kementerian Pendidikan dan Kebudayaan yang tersaji pada Tabel 1 (Kemendikbud, 2018).

Tabel 1. Rekapitulasi nilai rata-rata Ujian Nasional SMP 4 Taman Pemalang.

\begin{tabular}{lccc}
\hline \multirow{3}{*}{ Mata Pelajaran } & \multicolumn{3}{c}{ Tahun Ajaran } \\
\cline { 2 - 4 } & $\mathbf{2 0 1 6 /}$ & $\mathbf{2 0 1 5 /}$ & $\mathbf{2 0 1 4 /}$ \\
& $\mathbf{2 0 1 7}$ & $\mathbf{2 0 1 6}$ & $\mathbf{2 0 1 5}$ \\
\hline Bahasa Indonesia & 66,28 & 71,89 & 71,31 \\
Bahasa Inggris & 37,57 & 42,99 & 49,38 \\
Matematika & 42,28 & 35,05 & 40,26 \\
IPA & 47,19 & 47,73 & 46,77 \\
Rerata & 48,33 & 49,42 & 51,93 \\
\hline
\end{tabular}

Sumber: https://puspendik.kemdikbud.go.id/ hasil-un/

Dari Tabel 1 terlihat nilai rata-rata Ujian Nasional mata pelajaran matematika lebih rendah dari mata pelajaran lainnya pada tahun ajaran 2014/2015 dan 2015/2016, sedangkan pada tahun ajaran 2016/2017, mata pelajaran matematika memiliki nilai rata-rata Ujian Nasional terendah kedua dari mata pelajaran lainnya. Hal ini menunjukkan bahwa siswa memiliki prestasi belajar matematika yang rendah di SMP N 4 Taman Pemalang selama tiga tahun terakhir.
Dalam mendukung proses belajar mengajar, minat belajar juga tidak kalah penting. Minat belajar merupakan faktor pendorong siswa dalam belajar yang didasari atas ketertarikan atau rasa senang dan keinginan siswa untuk belajar (Astuti, 2015; Kartika, 2014; Ricardo \& Meilani, 2017; Supardi et al., 2012). Nurhasanah \& Sobandi (2016) apabila seseorang yang berminat dengan suatu pelajaran maka ia akan memiliki perasaan ketertarikan terhadap pelajaran tersebut. Ia akan rajin belajar dan terus memahami semua ilmu yang berhubungan dengan bidang tersebut, mengikuti pelajaran dengan antusias dan tanpa beban dalam dirinya. Sehingga minat mempunyai peranan penting dalam pencapaian keberhasilan prestasi belajar.

Safitri (2016) mengemukakan bahwa cara untuk mengetahui ada tidaknya minat terhadap suatu pelajaran dapat dilihat dari cara anak mengikuti pelajaran, lengkap atau tidaknya catatan, memperhatikan atau tidaknya dalam pelajaran tersebut. Berdasarkan observasi pembelajaran matematika di SMP N 4 Taman diketahui bahwa siswa memiliki minat belajar yang rendah, hal ini didukung dengan pernyataan serupa oleh guru matematika pada saat wawancara. Menurut Safitri (2016) kurangnya minat belajar siswa mengakibatkan pemahaman terhadap materi yang diajarkan tidak maksimal.

Terdapat banyak faktor yang mempengaruhi prestasi dan minat belajar siswa. Menurut Syarifuddin (2011) mengemukakan bahwa faktor tersebut adalah faktor dari dalam diri siswa (internal) dan faktor dari luar siswa eksternal. Faktor eksternal yang mempengaruhi prestasi dan minat belajar siswa adalah model pembelajaran. Masih banyak guru yang menggunakan model pembelajaran 
DOI: https://doi.org/10.24127/ajpm.v9i3.2804

konvensional yang menyebabkan kurang optimalnya pencapaian prestasi dan minat belajar.

Salah satu model pembelajaran yang diduga dapat mengatasi permasalahan tersebut yaitu Discovery Learning. Model ini berpusat pada siswa, yang dirancang untuk membantu siswa mengembangkan kemampuan berpikir dan memecahkan masalah kehidupan sehari-hari, dimana siswa dalam proses belajar terlibat aktif melalui penemuan sendiri dengan dibimbing pertanyaan guru, agar hasil yang diperoleh akan tahan lama dalam ingatan dan tidak mudah dilupakan (Fitri \& Derlina, 2015; Mawaddah \& Maryanti, 2016; Qodariyah \& Hendriana, 2015; Vahlia \& Agustina, 2016). Ciri utama model ini adalah mengeksplorasi dan memecahkan masalah untuk menciptakan, menggabungkan dan menggeneralisasikan pengetahuan, berpusat pada siswa, dan kegiatan menggabungkan pengetahuan baru dan pengetahuan yang ada (Istiana et al., 2015).

Telah banyak penelitian yang dilakukan sebelumnya mengenai prestasi belajar pada model Discovery Learning (Istiana et al., 2015; Khanah et al., 2019; Suminar \& Meilani, 2016; Witri, 2017). Begitu pula penelitian tentang minat belajar pada model pembelajaran ini, walaupun jumlahnya masih sedikit (Ma'aruf, 2016; Nugraha \& Sari, 2017). Namun, belum ditemukan penelitian tentang dampak model pembelajaran ini pada prestasi dan motivasi belajar secara bersamaan dengan analisis data yang kuat. Penelitian ini menawarkan statistik yang kuat dan hasil yang lebih komprehensif, karena dalam analisis datanya menggunakan MANOVA (Multivariate Analysis of Variance) yang mampu menganalisis beberapa variabel terikat secara simultan sehingga dapat memperkecil kesalahan tipe I $(\alpha)$ dalam pengambilan keputusan uji (Sutrisno \& Wulandari, 2018).

Berdasarkan penjelasan tersebut, maka penelitian ini mempunyai tujuan untuk mengetahui apakah prestasi dan minat belajar siswa yang menggunakan model Discovery Learning lebih baik daripada model pembelajaran konvensional.

\section{METODE PENELITIAN}

Penelitian ini merupakan penelitian eksperimen yang dilaksanakan di SMP Negeri 4 Taman Kabupaten Pemalang Tahun Ajaran 2018/2019. Desain eksperimen yang digunakan dalam penelitian ini adalah Quasi Experimental Design. Variabel dalam penelitian ini meliputi variabel bebas dan variabel terikat. Terdapat satu variabel bebas dalam penelitian ini yaitu model pembelajaran yang terdiri dari dua taraf yaitu model Discovery Learning dan model pembelajaran konvensional. Sedangkan variabel terikat dalam penelitian ini ada dua yaitu prestasi dan minat belajar.

Populasi penelitian ini adalah seluruh siswa kelas VII SMP N 4 Taman semester genap yang terdiri dari 8 kelas. Teknik pengambilan sampel pada penelitian ini menggunakan Cluster Random Sampling dimana hal ini dilakukan dengan pertimbangan bahwa kelas sampel yang diambil diampu oleh guru yang sama, kurikulum yang sama, dan menggunakan buku paket yang sama, siswa duduk pada tingkat kelas yang sama dan pembagian kelas tidak ada kelas unggulan. Sampel pada penelitian ini sebanyak dua kelas yaitu kelas VII D sebagai kelas kontrol dan kelas VII $\mathrm{H}$ sebagai kelas eksperimen, yang masing-masing berisi 
32 siswa. Selain itu, digunakan pula kelas VII A sebagai kelas uji coba instrumen yang berisi 32 siswa.

Teknik pengumpulan data dalam penelitian ini adalah tes uraian, angket, dan dokumentasi. Teknik dokumentasi digunakan untuk mendapatkan data prestasi belajar siswa sebelum diberikan perlakuan. Teknik tes uraian digunakan untuk mendapatkan data prestasi belajar siswa setelah diberi perlakuan. Teknik angket digunakan untuk mendapatkan data minat belajar siswa sebelum dan setelah diberi perlakuan. Instrumen penelitian terlebih dahulu divalidasi oleh para ahli untuk mengetahui validitas isinya, kemudian diujicobakan pada kelas VII A untuk mengetahui reliabilitas, taraf kesukaran, dan daya pembeda (konsistensi internal). Berdasarkan hasil analisis instrumen prestasi belajar, diperoleh soal yang memenuhi kriteria sebanyak 7 butir soal. Hasil analisis instrumen angket minat, diperoleh 27 butir pernyataan yang memenuhi kriteria.

Teknik analisis data awal menggunakan analisis multivariat. Penggunaan analisis ini memiliki keunggulan yaitu mampu menganalisis semua variabel terikat secara simultan, sehingga dapat memperkecil kesalahan tipe I $(\alpha)$ dalam pengambilan keputusan uji statistik (Sutrisno et al., 2013). Sebagai uji prasyarat analisis data maka perlu dilakukan uji normalitas distribusi multivariat menggunakan uji Mardia dan uji homogenitas matriks kovariansi menggunakan uji Box's M (Sutrisno \& Wulandari, 2018). Setelah semua persyaratan uji terpenuhi maka dapat dilakukan uji Hotelling Trace $\mathrm{T}^{2}$. Teknik analisis data akhir sama dengan teknik analisis data. Jika $\mathrm{H}_{0}$ ditolak pada uji Hotelling Trace $\mathrm{T}^{2}$ maka dilanjutkan dengan uji kesamaan rerata dengan menggunakan uji t pada masing- masing variabel terikat (Sari et al., 2019). Pada penelitian ini digunakan taraf signifikansi $5 \%$.

\section{HASIL DAN PEMBAHASAN}

Data awal prestasi belajar siswa berupa nilai ulangan, dan nilai minat belajar. Kemudian dilakukan uji normalitas distribusi multivariat untuk kelas eksperimen dan kontrol. Uji normalitas distribusi multivariat dilakukan untuk mengetahui apakah sampel berasal dari populasi berdistribusi normal multivariat. Hasil uji normalitas distribusi multivariat data awal dapat dilihat pada Tabel 2.

Tabel 2. Hasil uji normalitas distribusi multivariat data awal.

\begin{tabular}{|c|c|c|c|c|c|c|c|}
\hline \multirow[b]{2}{*}{ Kelas } & \multirow[b]{2}{*}{ n } & \multicolumn{2}{|c|}{$\mathbf{b}_{1, \mathbf{p}}$} & \multicolumn{3}{|c|}{$\mathbf{b}_{2, \mathbf{p}}$} & \multirow{2}{*}{$\begin{array}{c}\text { Kepu- } \\
\text { tusan } \\
\text { Uji }\end{array}$} \\
\hline & & Hitung & $\begin{array}{l}\text { Tabel } \\
\text { upper }\end{array}$ & Hitung & $\begin{array}{l}\text { Tabel } \\
\text { upper }\end{array}$ & $\begin{array}{l}\text { Tabel } \\
\text { lower }\end{array}$ & \\
\hline Kontrol & 32 & 0,747 & 1,613 & 8,357 & 5,727 & 10,557 & $\begin{array}{l}\mathrm{H}_{0} \text { di- } \\
\text { terima }\end{array}$ \\
\hline $\begin{array}{c}\text { Ekspe- } \\
\text { rimen }\end{array}$ & 32 & 0,421 & 1,613 & 8,922 & 5,727 & 10,557 & $\begin{array}{l}\mathrm{H}_{0} \text { di- } \\
\text { terima }\end{array}$ \\
\hline
\end{tabular}

Dari Tabel 2, pada kelas kontrol terlihat bahwa $b_{1, p}=0,747<b_{\text {tabel_upper }}=$ 1,613 dan $\mathrm{b}_{\text {tabel_upper }}=5,727<\mathrm{b}_{2, \mathrm{p}}=$ $8,357<b_{\text {tabel_lower }}=10,557$ dan pada kelas eksperimen terlihat bahwa $\mathrm{b}_{1, \mathrm{p}}=$ $0,421<b_{\text {tabel_upper }}=1,613$ dan $b_{\text {tabel_upper }}$ $=5,727<\mathrm{b}_{2, \mathrm{p}}=8,922<\mathrm{b}_{\text {tabel_lower }}=$ 10,557. Hal ini berarti $\mathrm{H}_{0}$ diterima maka dapat disimpulkan bahwa sampel kontrol dan eksperimen berasal dari populasi yang berdistribusi normal multivariat. Selanjutnya dilanjutkan dengan uji homogenitas matriks kovariansi data awal. Uji homogenitas matriks kovariansi dilakukan untuk mengetahui apakah kedua sampel diambil dari populasi memiliki matriks kovariansi homogen atau tidak. Hasil uji homogenitas kovariansi data awal dapat dilihat pada Tabel 3. 
DOI: https://doi.org/10.24127/ajpm.v9i3.2804

Tabel 3. Hasil uji homogenitas matriks kovariansi data awal.

\begin{tabular}{ccccc}
\hline Kelas & $\mathbf{n}$ & $\mathbf{F}_{\text {hitung }}$ & $\mathbf{F}_{\text {tabel }}$ & $\begin{array}{c}\text { Keputusan } \\
\mathbf{U j i}\end{array}$ \\
\hline $\begin{array}{c}\text { Kontrol } \\
\text { Eksperimen }\end{array}$ & 32 & 0,014 & 2,605 & $\mathrm{H}_{0}$ diterima \\
\hline
\end{tabular}

Dari Tabel 3, terlihat bahwa nilai $\mathrm{F}_{\text {hitung }}=0,014<\mathrm{F}_{\text {tabel }}=2,605$ maka $\mathrm{H}_{0}$ diterima. Hal ini berarti matriks kovariansi kedua kelompok sama (homogen). Selanjutnya dilanjutkan dengan uji Hotelling Trace $\mathrm{T}^{2}$ data awal. Uji Hotelling Trace $\mathrm{T}^{2}$ data awal dilakukan untuk mengetahui apakah rerata prestasi dan minat belajar siswa kelas eksperimen dan kelas kontrol sebelum diberi perlakuan adalah sama. Hasil uji Hotelling Trace $\mathrm{T}^{2}$ data awal dapat dilihat pada Tabel 4.

Tabel 4. Hasil uji Hotelling Trace $\mathrm{T}^{2}$ data awal.

\begin{tabular}{ccccc}
\hline Kelas & $\mathbf{n}$ & $\mathbf{T}_{\text {hitung }}^{2}$ & $\mathbf{T}_{\text {tabel }}^{2}$ & Keputusan Uji \\
\hline $\begin{array}{c}\text { Kontrol } \\
\text { Eksperimen }\end{array}$ & 32 & 0,6079 & 6,4004 & $\mathrm{H}_{0}$ diterima \\
\hline
\end{tabular}

Dari Tabel 4 terlihat bahwa nilai $\mathrm{T}^{2}{ }_{\text {hitung }}=0,6079<\mathrm{T}_{\text {tabel }}^{2}=6,4004$ maka $\mathrm{H}_{0}$ diterima. Hal ini berarti rerata prestasi dan minat belajar siswa kelas eksperimen dan kelas kontrol sebelum perlakuan adalah sama. Hal ini dimaksudkan agar dapat diyakini bahwa perubahan yang terjadi setelah perlakuan dapat dikaitkan dengan perlakuan yang diberikan, bukan dikarenakan hal lainnya.

Selanjutnya kelas kontrol dan kelas eksperimen diberikan perlakuan berbeda. Kelas kontrol diberi perlakuan dengan menggunakan model pembelajaran konvensional dan kelas eksperimen diberi perlakuan dengan menggunakan model Discovery Learning. Di akhir pemberian perlakuan, dilakukan tes prestasi dan angket minat belajar untuk memperoleh data akhir. Sebelum dilakukan uji hipotesis, terlebih dahulu dilakukan uji normalitas distribusi multivariat data akhir. Uji normalitas dilakukan untuk mengetahui apakah sampel berasal dari populasi berdistribusi normal multivariat. Hasil uji normalitas distribusi multivariat data akhir dapat dilihat pada Tabel 5.

Tabel 5. Hasil uji normalitas distribusi multivariat data akhir.

\begin{tabular}{|c|c|c|c|c|c|c|c|}
\hline \multirow[b]{2}{*}{ Kelas } & \multirow[b]{2}{*}{ n } & \multicolumn{2}{|c|}{$\mathbf{b}_{1, \mathbf{p}}$} & \multicolumn{3}{|c|}{$\mathbf{b}_{2, \mathrm{p}}$} & \multirow{2}{*}{$\begin{array}{c}\text { Kepu- } \\
\text { tusan } \\
\text { Uji }\end{array}$} \\
\hline & & Hitung & $\begin{array}{l}\text { Tabel } \\
\text { upper }\end{array}$ & Hitung & $\begin{array}{l}\text { Tabel } \\
\text { upper }\end{array}$ & $\begin{array}{l}\text { Tabel } \\
\text { lower }\end{array}$ & \\
\hline & 32 & & 1,613 & & 5,727 & 10,557 & \\
\hline & 32 & 0,276 & 1,613 & 5,848 & 5,727 & 10,557 & $\begin{array}{l}\mathrm{H}_{0} \text { di- } \\
\text { terima }\end{array}$ \\
\hline
\end{tabular}

Dari Tabel 5, pada kelas kontrol terlihat bahwa $\mathrm{b}_{1, \mathrm{p}}=1,565<\mathrm{b}_{\text {tabel_upper }}=$ 1,613 dan $b_{\text {tabel_upper }}=5,727<\mathrm{b} 2, \mathrm{p}=$ $7,340<b_{\text {tabel_lower }}=10,557$ dan pada kelas eksperimen terlihat bahwa $\mathrm{b}_{1, \mathrm{p}}=$ $0,276<b_{\text {tabel_upper }}=1,613$ dan $b_{\text {tabel_upper }}$ $=5,727<b_{2, p}=5,848<b_{\text {tabel_lower }}=$ 10,557. Hal ini berarti $\mathrm{H}_{0}$ diterima maka sampel kelas kontrol dan eksperimen berasal dari populasi yang berdistribusi normal multivariat. Selanjutnya dilanjutkan dengan uji homogenitas matriks kovariansi data akhir. Uji homogenitas matriks kovariansi dilakukan untuk mengetahui apakah kedua sampel diambil dari populasi homogen atau tidak. Hasil uji homogenitas matriks kovariansi data akhir dapat dilihat pada Tabel 6 .

Tabel 6. Hasil uji homogenitas matriks kovariansi data akhir.

\begin{tabular}{ccccc}
\hline Kelas & $\mathbf{n}$ & $\mathbf{F}_{\text {hitung }}$ & $\mathbf{F}_{\text {tabel }}$ & $\begin{array}{c}\text { Keputusan } \\
\text { Uji }\end{array}$ \\
\hline Kontrol & 32 & 1,381 & 2,605 & $\mathrm{H}_{0}$ diterima \\
Eksperimen & 32 & 1,38 \\
\hline
\end{tabular}


DOI: https://doi.org/10.24127/ajpm.v9i3.2804

Dari Tabel 6, terlihat bahwa nilai $\mathrm{F}_{\text {hitung }}=1,381<\mathrm{F}_{\text {tabel }}=2,605$ maka $\mathrm{H}_{0}$ diterima. Hal ini berarti matriks kovariansi kedua kelompok sama (homogen). Selanjutnya dilanjutkan dengan uji Hotelling Trace $\mathrm{T}^{2}$ data akhir. Uji Hotelling Trace $\mathrm{T}^{2}$ data akhir dilakukan untuk mengetahui apakah rerata prestasi dan minat belajar siswa kelas eksperimen dan kelas kontrol setelah diberi perlakuan adalah sama. Hasil uji Hotelling Trace $\mathrm{T}^{2}$ data akhir dapat dilihat pada Tabel 7.

Tabel 7. Hasil uji Hotelling Trace $\mathrm{T}^{2}$ data akhir

\begin{tabular}{ccccc}
\hline Kelas & $\mathbf{n}$ & $\mathbf{T}_{\text {hitung }}^{2}$ & $\mathbf{T}_{\text {tabel }}^{2}$ & Keputusan Uji \\
\hline $\begin{array}{c}\text { Kontrol } \\
32\end{array}$ & 15,2194 & 6,4004 & $\mathrm{H}_{0}$ ditolak \\
Eksperimen & 32 & & & \\
\hline
\end{tabular}

Dari Tabel 7, terlihat bahwa nilai $\mathrm{T}_{\text {hitung }}^{2}=15,2194>\mathrm{T}_{\text {tabel }}^{2}=6,4004$ maka $\mathrm{H}_{0}$ ditolak. Hal ini berarti terdapat perbedaan rerata prestasi dan minat belajar siswa kelas eksperimen dan kelas kontrol setelah perlakuan. Selanjutnya dilakuan uji pasca Hotelling Trace $\mathrm{T}^{2}$ menggunakan uji kesamaan rata-rata (uji t dua pihak). Berikut hasil uji kesamaan rata-rata pada variabel terikat prestasi belajar siswa yang hasilnya dapat dilihat pada Tabel 8 .

Tabel 8. Hasil uji kesamaan rata-rata pada prestasi belajar siswa.

\begin{tabular}{|c|c|c|c|c|c|c|}
\hline Kelas & n & $\overline{\mathbf{X}}$ & $\mathbf{s}$ & $\mathbf{t}_{\text {hitung }}$ & $\mathbf{t}_{\text {tabel }}$ & $\begin{array}{c}\text { Keputusan } \\
\text { Uji }\end{array}$ \\
\hline Kontrol & 32 & 74,50 & 7,15 & 3,476 & $\begin{array}{c}-1,99897 \\
\text { atau }\end{array}$ & $\mathrm{H}_{0}$ ditolak \\
\hline Eksperimen & 32 & 80,72 & & & 1,99897 & \\
\hline
\end{tabular}

Dari Tabel 8, terlihat bahwa $\mathrm{t}_{\text {hitung }}=3,476>\mathrm{t}_{\text {tabel }}=1,99897$ maka $_{0}$ ditolak. Hal ini berarti ada perbedaan prestasi belajar antara kelas eksperimen dan kelas kontrol. Diketahui rerata hitung kelas eksperimen adalah 80,72 dan rerata hitung kelas kontrol adalah 74,50, sehingga dapat disimpulkan bahwa prestasi belajar siswa pada kelas yang mendapat perlakuan model Discovery Learning lebih baik daripada pembelajaran konvensional. Selanjutnya dilakukan uji kesamaan rata-rata pada variabel terikat minat belajar siswa yang hasilnya dapat dilihat pada Tabel 9.

Tabel 9. Hasil uji kesamaan rata-rata pada minat belajar siswa.

\begin{tabular}{|c|c|c|c|c|c|c|}
\hline Kelas & $\mathbf{n}$ & $\overline{\mathbf{X}}$ & $\mathbf{s}$ & $\mathbf{t}_{\text {hitung }}$ & $\mathbf{t}_{\text {tabel }}$ & $\begin{array}{c}\text { Keputusan } \\
\text { Uji }\end{array}$ \\
\hline Kontrol & 32 & 76,78 & & & $-1,99897$ & \\
\hline Eksperimen & 32 & 80,15 & 6,48 & 2,083 & $\begin{array}{c}\text { atau } \\
1,99897\end{array}$ & $\mathrm{H}_{0}$ ditolak \\
\hline
\end{tabular}

Dari Tabel 9, terlihat bahwa $\mathrm{t}_{\text {hitung }}=2,083>\mathrm{t}_{\text {tabel }}=1,99897$ maka $_{0}$ ditolak. Hal ini berarti dapat dilihat bahwa ada perbedaan minat belajar antara kelas eksperimen dan kelas kontrol. Diketahui rerata hitung kelas eksperimen adalah 80,15 dan rerata hitung kelas kontrol adalah 76,78, sehingga dapat disimpulkan bahwa minat belajar siswa pada kelas yang mendapat perlakuan model Discovery Learning lebih baik daripada pembelajaran konvensional.

Hasil penelitian ini menunjukkan bahwa prestasi dan minat belajar siswa yang menggunakan model Discovery Learning lebih baik daripada model pembelajaran konvensional. Hal ini didukung pengamatan di lapangan bahwa selama proses pembelajaran, kelas yang menerapkan model Discovery Learning lebih aktif dalam kegiatan pembelajaran. Dalam kegiatan pembelajaran siswa dibagi menjadi beberapa kelompok. Masing-masing kelompok bekerjasama melakukan penemuan pada LKPD sesuai dengan yang sedang dipelajari. Pada proses 
pembelajaran yang berlangsung tercipta suasana belajar yang lebih aktif. Pada saat menyampaikan hasil, jika ada siswa yang kurang paham terjadi tanya jawab dan saling tukar pikiran sama lain sehingga semua siswa terlibat dalam kegiatan pembelajaran dan aktif dalam kegiatan pembelajaran yang bisa membuat minat siswa terhadap pelajaran matematika meningkat. Berbeda dengan kondisi tersebut, pada model pembelajaran konvensional siswa lebih pasif. Siswa hanya mendengarkan penjelasan dari guru. Saat guru bertanya, hanya beberapa siswa yang menjawab. Selain itu siswa hanya menghafal materi yang disampaikan, sehingga pada pertemuan selanjutnya siswa sudah lupa dengan materi yang telah dipelajari pada pertemuan sebelumnya.

Temuan-temuan hasil penelitian ini diperkuat oleh Witri (2017) menyebutkan bahwa penerapan model Discovery Learning dapat meningkatkan prestasi belajar siswa. Selain itu, Nordianti (2018) mengatakan bahwa terdapat perbedaan hasil belajar matematika antara siswa yang menerapkan model Discovery Learning dibandingkan dengan siswa yang memperoleh model pembelajaran konvensional. Hasil belajar siswa yang menggunakan model Discovery Learning lebih tinggi daripada model pembelajaran konvensional (Fitri \& Derlina, 2015; Hanggara \& Alfionita, 2015; Khanah et al., 2019; Mubarok \& Sulistyo, 2014). Model Discovery Learning memberikan pengaruh yang signifikansi dalam meningkatkan hasil belajar siswa (Kadri \& Rahmawati, 2015; Nugrahaeni et al., 2017; Setyowati et al., 2018; Zulfajri \& Amelia, 2016). Kemampuan berpikir kritis matematis siswa yang mendapat perlakuan model Discovery Learning lebih baik dari siswa yang mendapat perlakuan pembelajaran konvensional (Wati et al., 2018). Hasil belajar dan kemampuan berpikir kritis tersebut secara spesifik mengarah pada domain kognitif, yang erat kaitannya dengan prestasi belajar siswa. Suminar \& Meilani (2016) menyatakan bahwa model Discovery Learning dapat meningkatkan prestasi belajar siswa.

Selain pendapat-pendapat yang menyatakan bahwa model Discovery Learning berpengaruh terhadap prestasi belajar siswa, terdapat pula pendapatpendapat yang menyatakan bahwa model Discovery Learning berpengaruh terhadap minat belajar siswa. Nugraha \& Sari (2017) menyatakan bahwa terdapat peningkatan minat belajar siswa setelah mendapat model Discovery Learning. Hal ini didukung oleh Ma'aruf (2016) yang mengatakan bahwa penggunaan model Discovery Learning dapat meningkatkan minat belajar siswa.

\section{KESIMPULAN DAN SARAN}

Simpulan yang dapat ditarik dalam penelitian ini adalah prestasi dan minat belajar siswa yang menggunakan model Discovery Learning lebih baik daripada model pembelajaran konvensional. Berdasarkan hasil penelitian ini, maka guru matematika disarankan menggunakan model Discovery Learning untuk meningkatkan prestasi dan minat belajar siswa. Guru hendaknya juga memperhatikan karakteristik siswa agar proses pembelajaran berjalan dengan efektif, tujuan pembelajaran dapat tercapai, dan dapat meningkatkan minat belajar siswa. Selain untuk guru, diberikan saran juga untuk para peneliti. Hasil penelitian ini dapat digunakan sebagai referensi untuk melakukan penelitian yang lebih komprehensif 
dengan memandang bahwa hasil belajar siswa yang sangat beragam, tidak hanya satu varibel terikat saja yang diamati sebagai dampak dari proses pembelajaran seperti penelitian pada umumnya. Penelitian ini menggunakan model Discovery Learning, disarankan peneliti lainnya dapat mencoba menggunakan model pembelajaran inovatif lainnya. Pada penelitian ini juga hanya mengamati prestasi dan minat belajar, maka disarankan peneliti lain dapat mengamati variabel-variabel lainnya seperti motivasi, kemandirian belajar, dan keterampilan matematika untuk memperkaya hasil penelitian ini.

\section{DAFTAR PUSTAKA}

Astuti, S. P. (2015). Pengaruh Kemampuan Awal dan Minat Belajar Terhadap Prestasi Belajar Fisika. Formatif: Jurnal Ilmiah Pendidikan MIPA, 5(1), 68-75. https://doi.org/http://dx.doi.org/10. 30998/formatif.v5i1.167

Fitri, M., \& Derlina, D. (2015). Pengaruh Model Pembelajaran Discovery Learning Terhadap Hasil Belajar Siswa pada Materi Pokok Suhu dan Kalor. INPAFI (Inovasi Pembelajaran Fisika), 3(2), 89-96. https://doi.org/10.24114/inpafi.v3i 2.5130

Hanggara, Y., \& Alfionita, V. (2015). Eksperimentasi Model Pembelajaran Probing Prompting dan Discovery Learning Terhadap Hasil Belajar Matematika Ditinjau dari Minat Belajar Siswa Kelas VII SMP Negeri 3 Batam. Pythagoras, 4(2), 1-11. http://journal.unrika.ac.id/index.ph p/jurnalphythagoras/article/view/1 88
Istiana, G. A., Saputro, A. N. C., \& Sukardjo, J. S. (2015). Penerapan Model Pembelajaran Discovery Learning untuk Meningkatkan Aktivitas dan Prestasi Belajar Pokok Bahasan Larutan Penyangga pada Siswa Kelas XI IPA Semester II SMA Negeri 1 Ngemplak Tahun Pelajaran 2013/2014. Jurnal Pendidikan Kimia, 4(2), 65-73.

Kadri, M., \& Rahmawati, M. (2015). Pengaruh Model Pembelajaran Discovery Learning Terhadap Hasil Belajar Siswa pada Materi Pokok Suhu dan Kalor. Jurnal Ikatan Alumni Fisika Universitas Negeri Medan, 1(1), 21. https://doi.org/10.24114/jiaf.v1i1.2 692

Kartika, H. (2014). Pembelajaran Matematika Berbantuan Software Matlab sebagai Upaya Meningkatkan Kemampuan Komunikasi Matematis dan Minat Belajar Siswa SMA. Jurnal Pendidikan Unsika, 2(1), 24-35. https://doi.org/10.22342/jpm.10.2. 3637.93-108

Kemendikbud. (2018). Capaian Hasil Ujian Nasional. https://puspendik.kemdikbud.go.id/ hasil-un/

Khanah, N., Rasiman, R., \& Sutrisno, S. (2019). Efektivitas Model Project Based Learning (PJBL) dan Model Discovery Learning (DL) Berbantu Macromedia Flash Terhadap Prestasi Belajar Matematika Siswa Kelas VIII. Seminar Nasional Matematika dan Pendidikan Matematika (4th SENATIK), 135145. 
Lestari, I. (2015). Pengaruh Waktu Belajar dan Minat Belajar terhadap Hasil Belajar Matematika. Formatif: Jurnal Ilmiah Pendidikan MIPA, 3(2), 115-125. https://doi.org/10.30998/formatif.v $3 \mathrm{i} 2.118$

Ma'aruf, I. (2016). Pengaruh Model Discovery Learning Terhadap Minat Belajar Siswa Mata Pelajaran Sejarah Kelas XII IPS Di $\quad$ SMA Negeri 1 Kalirejo Lampung Tengah. Universitas Lampung.

Mawaddah, S., \& Maryanti, R. (2016). Kemampuan Pemahaman Konsep Matematis Siswa SMP dalam Pembelajaran Menggunakan Model Penemuan Terbimbing (Discovery Learning). EDU-MAT: Jurnal Pendidikan Matematika, 4(1), $\quad$ 76-85. https://doi.org/10.20527/edumat.v4 i1.2292

Mubarok, C., \& Sulistyo, E. (2014). Penerapan Model Pembelajaran Discovery Learning Terhadap Hasil Belajar Siswa Kelas X Tav Pada Standar Kompetensi Melakukan Instalasi Sound System Di Smk Negeri 2 Surabaya. Jurnal Pendidikan Teknik Elektro, 3(1), 215-221.

Nordianti, P. (2018). Pengaruh Model Pembelajaran Discovery Learning Terhadap Hasil Belajar Matematika Siswa Kelas IV SDN 2 Kampung Baru Tahun Ajaran 2017/2018. Universitas Lampung.

Nugraha, A. A., \& Sari, A. F. (2017). Pengaruh Model Pembelajaran Discovery Learning Terhadap
Minat Belajar Siswa pada Materi Trigonometri Kelas X. Prosiding SI MaNIs (Seminar Nasional Integrasi Matematika Dan Nilai Islami ), 123-127. http://conferences.uinmalang.ac.id/index.php/SIMANIS/ article/view/48

Nugrahaeni, A., Redhana, I. W., \& Kartawan, I. M. A. (2017). Penerapan Model Discovery Learning Untuk Meningkatkan Keterampilan Berpikir Kritis Dan Hasil Belajar Matematika. Jurnal Pendidikan Kimia, 1(1), 23-29. https://doi.org/10.31004/basicedu.v $3 \mathrm{i} 1.62$

Nurhasanah, S., \& Sobandi, A. (2016). Motivasi Belajar sebagai Determinan Hasil Belajar Siswa. Jurnal Pendidikan Manajemen Perkantoran, $4(1), \quad 80$. https://doi.org/10.17509/jpm.v4i1. 14958

Qodariyah, L., \& Hendriana, H. (2015). Mengembangkan Kemampuan Komunikasi dan Disposisi Matematik Siswa SMP Melalui Discovery Learning. Edusentris, 2(3), 241-252. https://doi.org/10.17509/edusentris .v2i3.177

Ricardo, R., \& Meilani, R. I. (2017). Impak Minat dan Motivasi Belajar Terhadap Hasil Belajar Siswa. Jurnal Pendidikan Manajemen Perkantoran, 2(2), 188-201. https://doi.org/10.17509/jpm.v2i2. 8108

Safitri, D. (2016). Penerapan Metode Mind Mapping untuk Meningkatkan Minat dan Hasil 
DOI: https://doi.org/10.24127/ajpm.v9i3.2804

Belajar IPA Siswa Kelas V SDN

Balangan 1. Jurnal Pendidikan Guru Sekolah Dasar, 5(3), 193203.

http://journal.student.uny.ac.id/ojs/ index.php/pgsd/issue/view/157

Sari, Y., Sutrisno, S., \& Sugiyanti, S. (2019). Experimentation of Problem Based Learning (PBL) Model on Student Learning Motivation and Achievement on Circle Material. Formatif: Jurnal Ilmiah Pendidikan MIPA, 9(4), 315-324.

https://doi.org/10.30998/formatif.v 9i4.3650

Setyowati, E., Kristin, F., \& Anugraheni, I. (2018). Penggunaan Model Pembelajaran Discovery Learning untuk Meningkatkan Kreativitas dan Hasil Belajar Siswa Kelas 5 SD Negeri Mangunsari 07. JUSTEK: Jurnal Sains \& Teknologi Jurnal Sains \& Teknologi, 1(1), 76-81.

Siagian, R. E. F. (2015). Pengaruh Minat dan Kebiasaan Belajar Siswa terhadap Prestasi Belajar Matematika. Formatif: Jurnal Ilmiah Pendidikan MIPA, 2(2), 122-131.

https://doi.org/10.30998/formatif.v $2 \mathrm{i} 2.93$

Suminar, S. O., \& Meilani, R. I. (2016). Pengaruh Model Pembelajaran Discovery Learning dan Problem Based Learning Terhadap Prestasi Belajar Peserta Didik. Jurnal Pendidikan Manajemen Perkantoran, 1(1), 80-89. http://ejournal.upi.edu/index.php/jp manper/article/view/00000
Supardi, Leonard, L., Suhendri, H., \& Rismurdiyati. (2012). Pengembangan Media Pembelajaran dan Minat Belajar Terhadap Hasil Belajar Fisika. Formatif: Jurnal Ilmiah Pendidikan MIPA, 2(1), 71-81. http://journal.lppmunindra.ac.id/in dex.php/Formatif/article/view/86/8 4

Sutrisno, S., Mardiyana, M., \& Usodo, B. (2013). Eksperimentasi Model Pembelajaran Kooperatif Tipe STAD dan TPS dengan Pendekatan SAVI terhadap Prestasi dan Motivasi Belajar ditinjau dari Gaya Belajar Siswa. Jurnal Elektronik Pembelajaran Matematika, 1(7), 661-671.

Sutrisno, S., \& Wulandari, D. (2018). Multivariate Analysis of Variance (MANOVA) untuk Memperkaya Hasil Penelitian Pendidikan. AKSIOMA: Jurnal Matematika Dan Pendidikan Matematika, 9(1), 37-53.

Syarif, I. (2012). Pengaruh Model Blended Learning Terhadap Motivasi dan Prestasi Belajar Siswa SMK. Jurnal Pendidikan Vokasi, 2(2), 234-249. https://doi.org/10.21831/jpv.v2i2.1 034

Syarifuddin, A. (2011). Penerapan Model Pembelajaran Cooperative: Belajar dan Faktor-Faktor yang Mempengaruhinya. Ta'dib, 16(1), 113-136.

Vahlia, I., \& Agustina, R. (2016). Perbandingan Hasil Belajar Discovery Learning Berbasis Problem Solving dan Group 
DOI: https://doi.org/10.24127/ajpm.v9i3.2804

Investigation Berbasis Problem Solving pada Pembelajaran Metode Numerik. AKSIOMA: Jurnal Program Studi Pendidikan Matematika, 5(1), 82-93. https://doi.org/10.24127/ajpm.v5i1. 469

Wati, D. A., Ariyanto, L., \& Sutrisno, S. (2018). Efektivitas Antara Model Pembelajaran Discovery Learning dengan Model Pembelajaran Pair Check terhadap Kemampuan Berpikir Kritis Matematis Siswa Kelas VII. Media Penelitian Pendidikan: Jurnal Penelitian Dalam Bidang Pendidikan Dan Pengajaran, 12(1), 12-25.

Witri, N. K. (2017). Penerapan Model Discovery Learning pada Pembelajaran Lingkaran untuk Meningkatkan Aktivitas dan Prestasi Belajar Siswa Kelas XI Kulit dan Musik Non Klasik SMK Negeri 5 Mataram Tahun Pelajaran 2016/2017. Universitas Mataram.

Zulfajri, M., \& Amelia, R. (2016). Pengaruh Model Discovery learning dengan Media Teka-Teki Silang Terhadap Peningkatan Hasil Belajar Siswa pada Materi Sistem Koloid. Jurnal Edukasi Kimia, 1(1), 12-18. 